Journal of Southeast Asian Studies, 48(1), pp 53-70 February 2017.

(C) The National University of Singapore, 2017 doi:10.1017/S0022463416000473

\title{
"We have resisted, now we must build": Regionalism and nation-building in Timor-Leste
}

\author{
Elfie Shiosaki
}

\begin{abstract}
During Timor-Leste's political and security crisis in 2006, a seemingly latent regional division re-emerged between Timorese from its eastern region, lorosa'e, and those from its western region, loromonu. The conflict between lorosa'e and loromonu revealed critical weaknesses in nation-building. Only four years after independence in 2002, international peacekeeping forces, led by Australia, were redeployed to the new nation-state. This article argues that the enduring political significance of regionalism weakens nation-building in Timor-Leste. This case study revitalises traditional security paradigms by relocating identity-building from the periphery of nationbuilding to its centre. Identity-building supports the formation of a unifying national political community which transcends social divisions within post-conflict societies.
\end{abstract}

Weak, failing or failed states are considered serious threats to international peace and stability. In the post-Cold War period, international and regional organisations have intervened in failing states, attempting to mitigate state failure or collapse through peacekeeping and peacebuilding operations. The United Nations has expanded its operations from traditional peacekeeping missions (which observe peace agreements) to multidimensional peacebuilding missions (which implement comprehensive peace agreements). Peacebuilding missions attempt to lay the foundations for sustainable peace, in particular by building liberal democratic states and institutions. UN missions have been carried out not only in situations of inter-state conflict but also intra-state conflict and civil wars.

At the turn of the twenty-first century, the United Nations further expanded its operations to nation-building. Sinclair Dinnen argues that 'the goal of nation-building in the broader sense is to unify the national community within the institutional framework of the modern state, with the objective of social and political stability'. ${ }^{1}$ In 1995 the United Nations carried out state construction in Bosnia and

Elfie Shiosaki is an Indigenous Post-Doctoral Research Fellow at the Centre for Human Rights Education at Curtin University in Perth, Western Australia. Correspondence in connection with this article should be addressed to: Elfie.Shiosaki@curtin.edu.au. The author would like to acknowledge the support of the University of Western Australia for this research.

1 Sinclair Dinnen, 'The twin processes of nation building and state building' (State, Society and Governance in Melanesia Program [SSGM] Briefing Note no. 1, The Australian National University [ANU], Canberra, 2007), p. 2. 
Herzegovina (UN Mission in Bosnia and Herzegovina, UNMIBH) and in 1999 it served as the administrator of both Kosovo (UN Interim Administration Mission in Kosovo, UNMIK), and Timor-Leste (UN Transitional Administration in East Timor, UNTAET). Dinnen concludes that nation-building is 'the favoured antidote' of the international community to the threats posed by state failure or collapse. ${ }^{2}$

In the aftermath of the 11 September 2001 terrorist attacks, there has been a shift towards a state-centric paradigm of international security and development. ${ }^{3}$ Security, peace and development have been inextricably linked to state-building, in particular to liberal democratic forms of statehood. ${ }^{4}$ The international community's interventions have reduced nation-building to a technical exercise of transferring a liberal democratic state. They have also reduced the nation-state to liberal democratic institutions.

Another cornerstone of nation-building is identity-building, which supports the emergence of a unifying national community which transcends social divisions within post-conflict societies. Identity-building consolidates and legitimises a new nationstate and mitigates the risk of further state failure or collapse. Such consolidation is evident in the criteria identified by Andrea Talentino for identity-building: the connection between citizens and the state; a sense of common purpose; the transfer of citizens' allegiance from local to central authority; and the erosion of social divisions. ${ }^{5}$

Nationalist narratives in post-conflict societies such as Timor-Leste's have significant implications for identity-building, in particular for the erosion of social divisions. The making of national history is a contested space because it is highly politicised and reflects broad balances of social and political power as well as struggles to tip those balances. As Umut Ozkirimli argues, 'the nationalist discourse does not arise in a social vacuum, but makes ample use of state and civil society institutions to sustain and reproduce itself. ${ }^{6}$ These narratives relate to claims of authenticity, which may be instrumentalised to articulate demands for access to state power and resources as well as social status.

This contested space of national history is occupied by unreconciled relationships between individuals and groups in the present and unreconciled narratives and

2 Ibid., pp. 1-2.

3 Mark R. Duffield, Development, security and unending war: Governing the world of peoples (Cambridge: Polity Press, 2007); Necla Tschirgi, 'Post-conflict peace-building revisited: Achievements, limitations, challenges', Paper presented at the WSP International/IPA Peacebuilding Forum Conference (New York: International Peace Academy, 2004).

4 Fen O. Hampson, Nurturing peace: Why peace settlements succeed or fail (Washington, DC: United States Institute of Peace Press, 1996); John P. Lederach, 'Civil society and reconciliation', in Turbulent peace: The challenges of managing international conflict, ed. Chester A. Crocker, Fen Hampson and Pamela Aall (Washington, DC: United States Institute of Peace Press, 2001), pp. 841-54; John Prendergast and Emily Plumb, 'Building local capacity: From implementation to peacebuilding', in Ending civil wars: The implementation of peace agreements, ed. Stephen J. Stedman, Donald Rothchild and Elizabeth M. Cousens (Boulder, CO: Lynne Rienner, 2002), pp. 327-49; Ian Smillie, ed., Patronage or partnership: Local capacity building in humanitarian crises (Bloomfield: Kumarian, 2001); Andrea K. Talentino, 'The two faces of nation-building: Developing function and identity', Cambridge Review of International Affairs 17, 3 (2004): 557-75.

5 Talentino, 'The two faces of nation-building'.

6 Umut Ozkirimli, Contemporary debates on nationalism: A critical engagement (London: Palgrave Macmillan, 2005), p. 164. 
counter-narratives of the past. As a result, nationalist narratives may locate dominant individuals and groups at the centre of history and others on the periphery. Such collective remembering and forgetting is described as 'a kind of amnesia', as past events which contest and negotiate official accounts of national history are excluded. ${ }^{7}$ Ozkirimli argues that 'we can easily unmask these claims once we see the past as providing a legacy of traditions and symbols for individuals and groups, and not as a fixed inheritance'. ${ }^{8}$ National history is continually being rewritten, and this rewriting process reflects internal power struggles. Ozkirimli argues that

nations do not have a single history: there are competing narratives to be told. Different factions, classes, religions, genders or ethnicities always struggle for the power to speak for the nation, and to present their particular voice as the voice of the whole nation, defining the history of other subsections accordingly. In other words, 'the voice of the nation' is a fiction. ${ }^{9}$

National history represents a messy entanglement of fact, fiction, and imagination.

If identity-building in post-conflict societies is fragile, nationalist narratives may not erode social divisions, but weave them into the fabric of a new nation-state. This case study of regionalism and nation-building in Timor-Leste revitalises traditional security paradigms by relocating identity-building from the periphery of nationbuilding to its centre.

\section{Emergence of the 'east-west divide' in 2006}

Timor-Leste is an ethnically, linguistically, and geographically diverse nation located on the boundary between Southeast Asia and the Pacific. James Fox describes the nation as 'not one place, but many'. ${ }^{10}$ In these many places, there are competing nationalist narratives which tell many stories of identity and belonging. Timor-Leste's history is layered with social divisions inherent in successive periods of resistance to Portuguese colonialism and Indonesian occupation - the legacy of the memory and trauma of conflict. During my fieldwork in Timor-Leste in 2008 and 2009, ${ }^{11}$ several interviewees emphasised that the foundations of the new nation-state had been built on this legacy. Henri Myrttinen argues that

like the pieces in a kaleidoscope, the conflicts in Timor Leste come in a range of various shapes and sizes. Some are bright and visible, others remain hidden from view. They overlap, link and lock into each other, they are reflected in each other, and with every turn of events, the shape, form, size and colour of the overall pattern produced changes. $^{12}$

7 Ibid., p. 190.

8 Ibid., p. 184.

9 Ibid.

10 James Fox, 'Tracing the path, recounting the past: Historical perspectives on Timor', in Out of the ashes: Destruction and reconstruction of East Timor, ed. James Fox and Dionisio Babo-Soares (Adelaide: Crawford House, 2000), p. 1.

11 I undertook around 50 interviews with Timorese and non-Timorese involved in nation-building in academic, community and government sectors during field research for my Ph.D. in 2008 and 2009.

12 Henri Myrttinen, 'Timor Leste - A kaleidoscope of conflicts', Watch Indonesia!, 1 Apr. 2008. 
Yet existing research on nation-building in Timor-Leste seems to neglect such diversity and divisions.

During Timor-Leste's political and security crisis in 2006, a seemingly latent regional division re-emerged between Timorese from its eastern region, lorosa'e, and those from its western region, loromonu. The crisis triggered the resignation of then prime minister Mari Alkatiri, and led to widespread violence. Yet the origin and nature of the east-wide divide are ambiguous. The 'east' generally refers to the three easternmost districts of Baucau, Lautém and Viqueque and the 'west' to the ten central and western districts of Aileu, Ainaro, Bobonaro, Cova-Lima, Dili, Ermera, Liquiçá, Manatuto, Manufahi and Oecusse. ${ }^{13}$ The Tetum term loro literally means sun while sa'e means to rise or come up and monu means to fall or go down. Lorosa'e means east, eastern or easterly - the direction of the sunrise. Loromonu means west, western or westerly - the direction of the sunset. The lorosa'e-loromonu dichotomy creates a division at Timor-Leste's geographical heart which is as irreconcilable as east and west. Ema lorosa'e describes Timorese from the eastern region of Timor-Leste or 'easterners' while ema loromonu describes those from the western region or 'westerners'. Colloquially, lorosa'e and loromonu describe easterners and westerners respectively. The Tetum terms firaku and kaladi are also used for easterners and westerners. ${ }^{14}$

The significance of the east-west divide is contested in Timorese studies. The lorosa'e and loromonu identities do not correlate with the diverse ethnolinguistic groups in Timor-Leste. Instead they appear to be latent identities of relatively obscure origin during the Portuguese colonial period. These identities became politicised during the resistance movement, ${ }^{15}$ and, to a lesser extent, during waves of rural-urban migration and displacement in Dili. ${ }^{16}$ The United Nations Independent Special Commission of Inquiry for Timor-Leste (UN Inquiry report), which investigated the 2006 crisis, concludes that critical institutional weaknesses and rivalries, particularly within the

13 There is no unambiguous geographical division between the 13 districts of Timor-Leste. In a controversial speech on 23 Mar. 2006, then president Xanana Kay Rala Gusmão accused the Revolutionary Front for an Independent East Timor (FRETILIN) government of favouring lorosa'e. In the speech, he described the western districts as being from Manatuto to Oecusse.

14 There are two theories about the roots of the Tetum terms firaku and kaladi. Some believe them to be of Portuguese origin: firaku from vira o cu, 'turn one's backside to the speaker', and kaladi from calado, meaning quiet or reserved. Dionisio Babo-Soares, in 'Branching from the trunk: East Timorese perceptions of nationalism in transition' (Ph.D. diss., ANU, 2003, pp. 269-70), argues that most Timorese believe that the Portuguese used these terms to stereotype the behaviour of lorosa'e and loromonu. Others believe that the terms have Indigenous origins: firaku from the Macassae language of Baucau ( $f i$, 'we' or 'us' and raku 'family' or 'relatives'), firaku often meaning friends or comrades; and kaladi from the Malay keladi (yam), grown by the Mambai, Kemak and Bunak communities in the central western highlands.

15 Babo-Soares, 'Branching from the trunk'; Andrew McWilliam, 'East and West in Timor-Leste: Is there an ethnic divide?', in The crisis in Timor-Leste: Understanding the past, imagining the future, ed. Dennis Shoesmith (Darwin: Charles Darwin University Press, 2003), pp. 37-44; James Scambary, Hippolito Da Gama and João Barreta, 'A survey of gangs and youth groups in Dili, Timor-Leste' (Dili: AusAID, 2006); Sven G. Simonsen, 'The authoritarian temptation in East Timor: Nation-building and the need for inclusive governance', Asian Survey 46, 4 (2006): 575-96.

16 Andrew Harrington, 'Ethnicity, violence, and land and property disputes in Timor-Leste', East Timor Law Journal 2 (2007); http://easttimorlawjournal.blogspot.com.au/2012/05/ethnicity-violence-landand-property.html (last accessed 24 Oct. 2016). 
security sector, and weak rule of law were the most significant causes of the crisis. ${ }^{17}$ However, the report also concludes that the crisis had deep roots in the Portuguese colonial period and Indonesian occupation, both of which had 'created and subsumed' social divisions:

many Timorese view the events of April and May 2006 as a continuum starting from the decolonization process in 1974/75 and encompassing the violence and factionalism of the Indonesian occupation and the violence that accompanied the United Nationssponsored Popular Consultation in 1999.18

While the re-emergence of the east-west divide during the 2006 crisis seemed to take many international observers by surprise, analysis of existing research indicates that the divide correlates with a divisive national discourse about the competing roles of lorosa'e and loromonu during the resistance. The geographical location of these regions had strategic advantages and disadvantages. The resistance was strongest in the eastern region of Timor-Leste because of its distance from the border with West Timor and its mountainous terrain. The last bastion of the resistance was Mount Matebian in Baucau. The military wing of the resistance movement, the National Liberation Forces of Timor-Leste (FALINTIL), was more active in the east. These strategic advantages contributed to a perception that the eastern region put up a stronger fight. During the 2006 crisis, some protestors reportedly carried banners stating "Brigadier General Ruak should declare "westerners" were also involved in the independence struggle'. ${ }^{19}$

The pro-autonomy militia groups, supported by the Indonesian military, were more active in the western region because of its proximity to the border and, as a result, more loromonu were coerced into these groups. This strategic disadvantage contributed to the perception that loromonu were more pro-autonomy. These militia groups reigned terror in the lead-up to and following the referendum for independence on 30 August 1999. The groups responsible for the greatest violence were based in western districts, including Aitarak (Thorn) in Dili, Besi Merah Putih (Iron, Red and White) in Liquiçá, Laksaur (Eagle) in Cova-Lima and Mahidi, Dead or Alive for Integration, in Ainaro. ${ }^{20}$

In the lead-up to the referendum, some of these groups claimed that the western region was pro-autonomy. ${ }^{21}$ In April 1999 leaders of Aitarak and Besi Merah Putih held a pro-autonomy demonstration at Government Palace during which the leader of Aitarak, Eurico Guterres, proposed dividing Timor-Leste along regional lines. ${ }^{22}$ Under his proposal, western districts would become an autonomous region of Indonesia, even if eastern districts voted in favour of independence. The

17 Office of the United Nations High Commissioner for Human Rights (OHCHR), 'Report of the United Nations Independent Special Commission of Inquiry for Timor-Leste' [UN Inquiry report] (Geneva: United Nations, 2006), p. 16.

18 Ibid.

19 Richard Curtain, 'Crisis in Timor-Leste: Looking beyond the surface reality for causes and solutions' (SSGM Working Paper 2006/1, ANU, Canberra), p. 12.

20 Babo-Soares, 'Branching from the trunk', pp. 67-8.

21 Douglas A. Kammen, 'Subordinating Timor: Central authority and the origins of communal identities in East Timor', Bijdragen tot de Taal-, Land-en Volkenkunde 166, 2-3 (2010): 257-8.

22 Kammen, 'Subordinating Timor': 258. 
Indonesian flag was more prominently displayed in Bobonaro, Cova-Lima, Ermera and Liquiçá. ${ }^{23}$ Reflecting the international community's concern about regional divisions in the lead-up to the referendum, the protocols for the referendum included a provision that ballot papers from all 13 districts would be mixed to hide regional patterns of voting. ${ }^{24}$

These strategic advantages and disadvantages are the root cause of the east-west divide which re-emerged during the 2006 crisis and are an enduring legacy of conflict. They contributed to divisive stereotypes that loromonu put up a weaker fight during the resistance, participated more actively in the militias, and were pro-autonomy. Paulo Castro Seixas argues that "Loromonu was synonymous to many Timorese as the "great door of invasion" and of "collaborationism" and, on the contrary, Lorosae was the same as "real warriors" and "resistants". ${ }^{25}$ Joanne Wallis argues that loromonu were characterised as 'Indonesia's "accomplices" in its occupation'.26 This narrative associated FALINTIL, and the political wing of the resistance movement, the Revolutionary Front for an Independent East Timor (FRETILIN), with the eastern region and lorosa'e and pro-autonomy and pro-independence groups with the western region and loromonu. ${ }^{27}$ The insult of 'if you're not FRETILIN, you're nothing' continued to cause great offence during interviews in 2009. ${ }^{28}$

In the post-independence period, this divisive narrative of 'heroes' and 'traitors' or 'victors' and 'villains' has informed antagonism between lorosa'e and loromonu. In late December 1999 a fight broke out between lorosa'e and loromonu youth near Areia Branca beach in Dili because lorosa'e youth had claimed that lorosa'e had put up a stronger fight during the resistance. ${ }^{29}$ The incident was followed by further fighting a few days later in early January 2000 at the Central Market in Dili during which kiosks owned by lorosa'e were burnt down and two lorosa'e were killed, reportedly in retribution for the first incident. ${ }^{30}$ Three weeks later a larger fight broke out in the Bairro Pite area in Dili, a loromonu area, during which many youth were injured. FALINTIL veterans had joined lorosa'e youth in the fight. Such instances of violence continued until the 2006 crisis.

Prior to 2006, violence relating to the east-west divide was evident between martial arts groups (MAGs), with some incidents involving FALINTIL veterans. ${ }^{31}$ The divide was also evident within both the FALINTIL Timor-Leste Defence Force (F-FDTL) and the Timor-Leste National Police (PNTL). ${ }^{32}$ When F-FDTL was

23 David Hicks, "Ema Lorosa'e", "Ema Loromonu": Identity and politics in Timor-Leste', in East-Timor: How to build a new nation in Southeast Asia in the 21st century: Proceedings of the EUROSEAS Congress in September 2007, ed. Christine Cabasset-Semedo and Frederic Durand (Bangkok: IRASEC, 2009), p. 90.

24 Hicks, "Ema Lorosa'e”, "Ema Loromonu”, p. 91.

25 Paulo Seixas, 'Translation as crisis, crisis as translation', in Cabasset-Semedo and Durand, East-Timor, p. 76.

26 Joanne Wallis, 'Villians, victors and victims: Capitalizing on memory in Timor-Leste', Ethnopolitics

12, 2 (2013): 138.

27 Ibid.

28 Personal communication, 20 Oct. 2009.

29 Babo-Soares, 'Branching from the trunk', p. 278.

30 Ibid., p. 280.

31 Ibid.

32 OHCHR, 'UN Inquiry report'. 
established in the post-independence period, soldiers were originally selected from FALINTIL veterans. The composition of F-FDTL, 56 per cent lorosa'e, did not reflect the national average of 35 per cent lorosa'e and 65 per cent loromonu. F-FDTL leadership implemented a targeted policy to correct the regional imbalance within recruitment and by 2006 the composition of F-FDTL reflected the national average. Yet around 50 per cent of officers remained lorosa'e, reflecting a regional imbalance between senior and junior ranks.

In 2004 the Los Palos report noted tension between veterans and new recruits within F-FDTL, in particular because older veterans were given preferred static assignments, seemingly due to their status, age and health. ${ }^{33}$ The UN Inquiry report concluded that in the context of the over-representation of ex-FALINTIL easterners in the officer ranks, disagreements easily became conflated with east versus west disputes'. ${ }^{34}$ The UN Inquiry report argues that the divide manifested itself in 'actual or perceived acts of discrimination and nepotism'. ${ }^{35}$ In an effort to correct regional imbalances in recruitment, F-FDTL introduced a new promotions policy which led to an increase in promotions for loromonu. ${ }^{36}$ Yet tensions remained within F-FDTL.

The issue was elevated to the national political agenda in early 2006 when around 150 officers and other ranks of F-FDTL submitted a petition to the Timorese Government which alleged discrimination against lorosa'e in F-FDTL. These soldiers became known as the 'Petitioners'. The labour dispute festered for several months, with the Petitioners swelling to almost 600 soldiers, and eventually triggered a national political and security crisis. Following the outbreak of armed confrontation between F-FDTL and PNTL, ${ }^{37}$ the Petitioners and their symbolic rebel leader Major Alfredo Reinado came to represent a 'justice movement' to end discrimination against loromonu. ${ }^{38}$

The 2006 crisis triggered the resignation of then prime minister Mari Alkatiri as well as minister of defence Roque Rodrigues and minister of the interior Rogerio Lobato. The two ministers were accused of illegally transferring weapons to civilians during the crisis. ${ }^{39}$ Widespread violence led to a significant loss of life, injuries and displacement as well as the destruction of property and critical infrastructure. Youth and MAGs from both east and west became involved in the conflict. The UN Inquiry report found that the violence on the streets of Dili had 'assumed an east versus west dynamic'. ${ }^{40}$ An estimated 150,000 Timorese were displaced by the

\footnotetext{
33 Quoted in ibid., p. 54.

34 Ibid.

35 Ibid., pp. 20-21.

36 Ibid., p. 54.

37 On 3 May 2006, Major Alfredo Reinado, Commander of the PNTL Military Police, abandoned his post along with F-FDTL and PNTL officers, then met with the Petitioners. His group was responsible for subsequent attacks on F-FDTL and PNTL. Reinado and 14 of the group were arrested by Portuguese paramilitary police on 26 July 2006. All escaped on 30 August and went into hiding. He remained in hiding until February 2008.

38 Matthew B. Arnold, 'Challenges too strong for the nascent state of Timor Leste: Petitioners and mutineers', Asian Survey 49, 3 (2009): 435.

39 OHCHR, 'UN Inquiry report'.

40 Ibid., p. 22.
} 
violence and some remained in Internally Displaced Person (IDP) camps in Dili and the districts until late 2009.

The divisive national discourse about the competing roles of lorosa'e and loromonu in the resistance had been embedded into nation-building in Timor-Leste. Regionalism remained as shadowy lines which intersected the political landscape in the new nation-state, as explained by one party official: 'it [the divide] influences the way Timorese conceptualise party politics' ${ }^{41}$ Dionisio Babo-Soares concludes that many Timorese affiliated regions with political parties, describing them as connecting 'who belongs to what' with 'who supports whom'. ${ }^{42}$ Specific suco, districts, and aldeia, hamlets, 'belonged' to specific parties. ${ }^{43}$

The re-emergence of the east-west divide in 2006 appears to have entrenched a negative form of political competition in the party system. The parliamentary election held in Timor-Leste in 2007 was marred by violent conflict of an east-west nature and the election results indicated that there was a strong relationship between region and party affiliation. A regional analysis of the election results indicates that FRETILIN's share of the vote in the three eastern districts was disproportionately high, accounting for 52 per cent of its total vote. The National Congress for the Reconstruction of Timor's (CNRT) share of the vote in the eastern districts was disproportionately low, accounting for only 15 per cent of its total vote. The minor parties had regional political support bases, with the Timorese Social Democratic Association (ASDT)/ Social Democrat Party (PSD), the Association of Timorese Heroes (KOTA), the Democratic Party (PD) and the National Unity Party (PUN) having their base in western districts and the National Unity of Timorese Resistance (UNDERTIM) in eastern districts. Such regional imbalances led to the characterisation of FRETILIN and UNDERTIM as so-called 'eastern' parties and CNRT and the other minor parties as 'western' parties. CNRT, led by then prime minister Xanana Kay Rala Gusmão, formed the Alliance for a Parliamentary Majority (AMP) coalition government with ASDT/PSD and PD.

The death of Reinado during an attempted assassination attempt against then president José Ramos Horta and prime minister Gusmão on 12 February 2008, appears to have led to the decline of the east-west divide. Reinado was believed to be the primary agitator of the lorosa'e-loromonu divide, representing the grievances of loromonu within the PNTL and, as a fugitive, becoming a symbol of their struggle against perceived discrimination. His death rendered the Petitioners leaderless and the group appeared to disband. The AMP coalition government effectively demobilised the Petitioners through a cash payment scheme in 2008. ${ }^{44}$ These payments were also made to veterans and their survivors, IDPs, and vulnerable groups such as the elderly.

However the east-west divide resonated more broadly in Timor-Leste, beyond the security sector, because of its correlation with the divisive national discourse about the roles of lorosa'e and loromonu during the resistance. The disbandment of the Petitioners may have resolved the crisis in the security sector, but not the crisis

41 Personal communication, 6 Dec. 2008.

42 Babo-Soares, 'Branching from the trunk', p. 147.

43 Ibid.

44 Wallis, 'Villians, victors and victims'. 
in national identity. A Timorese peacebuilding officer explained to me that the death of Reinado 'had cut down the trunk of the tree, but had not dug out its roots' ${ }^{45}$ In the aftermath of the 2006 crisis, the divide was rarely referred to in public debate or official communication, but this did not indicate a resolution to the conflict. The divide had become taboo. Interviewees would discuss it in whispers with nervous glances for fear of being overheard. Despite this my research demonstrated that the divide continued to be politically significant, but there was no broad consensus on its origin or nature. Negative stereotypes about lorosa'e and loromonu continued to inform strongly held beliefs about each group's contribution to the resistance. Around half of the interviewees believed the divide was significant, and a majority believed Timorese were vulnerable to further political manipulation around this divide.

A majority of interviewees believed that post-independence identity-building was fragile. Regionalism was undermining the formation of a unifying national community. One way to plot the course of regionalism since this period is to compare the role it played in the parliamentary elections in 2007 and 2012. If regionalism continued to intersect the political landscape, then regional polarisation should be evident in an analysis of the 2012 election results, as it was in the 2007 elections.

\section{Regionalism in the 2012 elections}

The presidential and parliamentary elections held in Timor-Leste in 2012 were a significant milestone for the new nation. The elections resulted in political change: the appointment of a new president, José Maria de Vasconcelos, also known as 'Taur Matan Ruak' (TMR), former commander of F-FDTL and last commander of FALINTIL during the resistance. They also resulted in political continuity: the re-election of then prime minister Gusmão; the re-election of his party, CNRT, as the senior partner of a coalition government; and the return of FRETILIN to opposition.

The Timorese Government assumed primary responsibility for running the elections, which consequently were viewed as a litmus test of state-building. The presidential elections on 17 March and 16 April and the parliamentary election on 7 July were intersected by another milestone, the anniversary of one decade of independence on 20 May. The withdrawal of the United Nations and International Stabilisation Force (ISF) from Timor-Leste at the end of 2012 had been made contingent on successful elections.

The 2012 parliamentary election was held on 7 July. ${ }^{46}$ Voter turnout was 74.78 per cent, compared with 81.79 per cent in the 2007 elections. Twenty-one political parties contested the parliamentary election, many of which were newly established micro parties. ${ }^{47}$ No party won a parliamentary majority of 33 seats. The election revealed widespread public satisfaction with then prime minister Gusmão and the performance of his party, CNRT. CNRT won 30 seats, with 36.66 per cent,

45 Personal communication, 17 Dec. 2008.

46 There are 65 seats in the National Parliament. Members are elected using a closed list proportional representation system, with one national constituency. Members are elected to serve five-year terms.

47 The Timorese electoral system sets a 3 per cent threshold to win seats in the National Parliament to limit the fragmentation of the political party system. Many of the new micro parties failed to meet this threshold, ruling out around 20 per cent of the vote. 
FRETILIN 25, with 29.87 per cent, PD 8, with 10.31 per cent, and a new party, Frente-Mudança, 2, with 3.11 per cent. In comparison with the 2007 elections, CNRT won an additional 12 seats and FRETILIN an additional 4 seats. PD retained its 8 seats. Many parties lost seats in the election, including junior partners in the AMP coalition government. ASDT/PSD lost their 11 seats, PUN lost its 3 seats, KOTA/People's Party of Timor (PPT) lost their 2 seats and UNDERTIM lost its 2 seats. SEARCH argues that CNRT's increased vote was not at the expense of FRETILIN, but its junior coalition parties. ${ }^{48}$

There is broad consensus that the 2012 elections were a resounding success. The United Nations commended the National Election Commission (CNE) and the Technical Secretariat for Electoral Administration (STAE) for their successful administration of the elections as well as the PNTL for ensuring a peaceful and stable environment during the electoral process. ${ }^{49}$ The Australia Timor-Leste Friendship Network (AusTimorFN) concluded that the parliamentary elections 'substantially complied with internationally recognised standards for free and fair elections'.50 Election observers reported that the election was held in a calm and orderly manner and voters were free from intimidation. ${ }^{51}$ Polling operations and closing and counting procedures were evaluated as good or outstanding in a large majority of polling centres. ${ }^{52}$ District tabulation was evaluated as transparent or very transparent in most cases. ${ }^{53}$ The AusTimorFN confidently declared 'it is clear that Timor-Leste is now able to run its own electoral process'. ${ }^{54}$

Could the 2012 elections also be viewed as a litmus test of identity-building? The emergence of the east-west divide during the 2006 crisis and the 2007 elections indicated that identity-building in the post-independence period was fragile. Had the divide declined in the post-crisis period, or was it latent, with deep roots buried underneath the surface?

\section{Regional analysis of parliamentary election results}

While international observers declared the 2012 elections in Timor-Leste to be free and fair, and the UN and ISF upheld their decision to withdraw from Timor-Leste, the elections alone are not evidence of the consolidation of nationbuilding. The parliamentary election in Timor-Leste in 2012 was not as afflicted by regionalism and violence of an east-west nature as the 2007 elections. However,

48 SEARCH, 'Timor-Leste 2012 Parliamentary Election outcomes', East Timor and Indonesia Action Network (ETAN), 18 July 2012; https://lists.riseup.net/www/arc/east-timor/2012-07/msg00192.html (last accessed 24 Oct. 2016).

49 United Nations, 'UN chief congratulates Timor-Leste on peaceful holding of parliamentary elections', United Nations News Centre, 8 July 2012; http://www.un.org/apps/news/story.asp? NewsID=42420\#.V9tOx4WzKHk (last accessed 24 Oct. 2016).

50 Australia Timor-Leste Friendship Network (AusTimorFN) and Deakin University's Centre for Citizenship, Development and Human Rights (CCDHR), 'Parliamentary Elections 7 July 2012' (Melbourne: CCDHR, 2012), p. 2.

51 Ibid., p. 5.

52 European Union Election Observer Mission (EUEOM), 'Timor-Leste, Final Report, Parliamentary Election 2012' (Brussels: EU, 2012), p. 5.

53 Ibid., pp. 5-6.

54 AusTimorFN and CCDHR, 'Parliamentary elections 7 July 2012', p. 2. 
Table 1: CNRT: Parliamentary election results 2012 and 2007

\begin{tabular}{|c|c|c|c|c|}
\hline \multirow[b]{3}{*}{ District } & \multicolumn{4}{|c|}{ CNRT } \\
\hline & \multicolumn{2}{|c|}{2012} & \multicolumn{2}{|c|}{2007} \\
\hline & Vote (\%) & $+/-$ & Vote (\%) & $+/-$ \\
\hline Aileu & 52.54 & +32 & 20.5 & - \\
\hline Ainaro & 37.19 & +25 & 11.8 & - \\
\hline Baucau & 23.05 & +10 & 13.4 & - \\
\hline Bobonaro & 37.65 & +17 & 20.6 & - \\
\hline Cova-Lima & 31.83 & +16 & 15.4 & - \\
\hline Dili & 49.54 & +4 & 45.2 & - \\
\hline Ermera & 40.67 & +27 & 13.6 & - \\
\hline Lautém & 20.24 & +6 & 14.6 & - \\
\hline Liquiçá & 41.99 & +3 & 39 & - \\
\hline Manatuto & 45.39 & +12 & 33.2 & - \\
\hline Manufahi & 31.37 & +18 & 13.8 & - \\
\hline Oecusse & 38.98 & +4 & 34 & - \\
\hline Viqueque & 16.29 & +4 & 12.6 & - \\
\hline Total & 36.66 & +13 & 24.01 & - \\
\hline
\end{tabular}

Source: www.staetl.com

the relationship between region and party affiliation has only moderated very slightly. Any moderation appears to be uneven.

A district analysis of the parliamentary election results indicates that CNRT's share of the vote in the eastern districts remains disproportionately low and FRETILIN's share of the vote in these districts remains disproportionately high (tables 1 and 2). CNRT's share of the vote in the eastern districts has stagnated. CNRT won its largest increase in support in the western districts of Aileu, Ainaro and Ermera. The party's performance in the eastern districts improved modestly, but its share of the vote in the eastern districts remained disproportionately low, accounting for only around 14 per cent of its total vote.

FRETILIN's share of the vote in the eastern districts has declined and the party has made some moderate or slight gains in the central and western districts. But the party's share of the vote in the eastern districts remains disproportionately high, accounting for around 43 per cent of its total vote. These districts remain a stronghold for the party; its performance in the central and western districts improved modestly, except for Cova-Lima and Oecusse, where it deteriorated. PD is the first party to gain genuine cross-regional support. PD's share of the vote in the eastern districts of Baucau, Lautém and Viqueque accounts for around 22 per cent of its total vote, which is significantly higher than CNRT's (Table 3).

The 2012 election revealed that the potential trajectory of regional polarisation, as indicated in the 2007 election, has declined to an extent. Following the 2012 election, the most divisive political division appeared to be between FRETILIN and 
Table 2: FRETILIN: Parliamentary election results, 2012, 2007 and 2001

\begin{tabular}{|c|c|c|c|c|c|}
\hline \multirow[b]{3}{*}{ District } & \multicolumn{5}{|c|}{ FRETILIN } \\
\hline & \multicolumn{2}{|c|}{2012} & \multicolumn{2}{|c|}{2007} & \multirow{2}{*}{$\begin{array}{c}2001 \\
\text { Vote (\%) }\end{array}$} \\
\hline & Vote (\%) & $+/-$ & Vote & $+/-$ & \\
\hline Aileu & 14.94 & +7 & 8.3 & -13 & 21.2 \\
\hline Ainaro & 13.29 & +3 & 9.9 & -18 & 27.6 \\
\hline Baucau & 51.38 & -11 & 62.4 & -20 & 82 \\
\hline Bobonaro & 17.77 & +2 & 16.1 & -41 & 57.4 \\
\hline Cova-Lima & 26.42 & -2 & 28.6 & -33 & 61.4 \\
\hline Dili & 28.4 & +6 & 22.4 & -32 & 54.6 \\
\hline Ermera & 19.92 & +6 & 13.9 & -18 & 31.9 \\
\hline Lautém & 43.86 & -2 & 45.5 & -17 & 62.8 \\
\hline Liquiçá & 23.79 & +12 & 12 & -60 & 72.4 \\
\hline Manatuto & 20.52 & +3 & 17.6 & -30 & 47.6 \\
\hline Manufahi & 31.86 & +6 & 25.4 & -29 & 54.6 \\
\hline Oecusse & 18.6 & -9 & 27.5 & -11 & 38.6 \\
\hline Viqueque & 59.52 & -0.5 & 60 & -15 & 75 \\
\hline Total & 29.87 & +1 & 29.02 & -28 & 57.37 \\
\hline
\end{tabular}

Source: www.staetl.com

Table 3: PD: Parliamentary election results, 2012, 2007 and 2001

\begin{tabular}{|c|c|c|c|c|c|}
\hline \multirow[b]{3}{*}{ District } & \multicolumn{5}{|c|}{ PD } \\
\hline & \multicolumn{2}{|c|}{2012} & \multicolumn{2}{|c|}{2007} & \multirow{2}{*}{$\begin{array}{c}2001 \\
\text { Vote (\%) }\end{array}$} \\
\hline & Vote (\%) & $+/-$ & Vote (\%) & $+/-$ & \\
\hline Aileu & 6.02 & - & 6.1 & +5 & 1.5 \\
\hline Ainaro & 15.05 & +3 & 12.8 & +7 & 6.2 \\
\hline Baucau & 3.96 & +1 & 2.7 & -1 & 3.6 \\
\hline Bobonaro & 14.53 & -5 & 19.3 & +8 & 11.2 \\
\hline Cova-Lima & 19.77 & -1 & 20.7 & +15 & 6.1 \\
\hline Dili & 7.05 & - & 6.7 & +2 & 4.8 \\
\hline Ermera & 6.95 & -15 & 22 & +2 & 20 \\
\hline Lautém & 20.64 & +7 & 13.7 & +4 & 10.1 \\
\hline Liquiçá & 12.71 & - & 12.4 & +7.5 & 4.9 \\
\hline Manatuto & 12.06 & -1 & 12.7 & +1 & 11.7 \\
\hline Manufahi & 8.09 & -4 & 11.7 & +8 & 3.5 \\
\hline Oecusse & 12.15 & - & 11.7 & +4 & 7.6 \\
\hline Viqueque & 8.43 & +5 & 3.8 & - & 3.5 \\
\hline Total & 10.31 & -1 & 11.3 & +3 & 8.72 \\
\hline
\end{tabular}


non-FRETILIN groups. SEARCH concludes that 'Gusmao has consolidated the anti-FRETILIN vote around his party, wiping out several of his coalition partners in the process; but has failed to make any inroads into FRETILIN's own support base. ${ }^{55}$ CNRT's coalition building with minor political parties Frente-Mudança and PD does not represent an alliance of so-called western parties, as the AMP coalition government may have. It more likely represents a consolidation of non-FRETILIN groups against FRETILIN.

While an analysis of these election results by district does not support an unambiguous line of division between eastern and western districts, the relationship between region and political affiliation continues to be strong. Michael Leach argues that while FRETILIN continues to dominate the eastern districts and the other parties the western and central districts, the results of the 2012 election could potentially represent an easing of the 'peak' of regional political alliances. ${ }^{56}$

However, any slight moderation of the relationship between region and political affiliation is uneven as a regional analysis of each of the major political parties' vote (CNRT and FRETILIN) tells a different story. CNRT's share of the vote in the eastern districts remains disproportionately very low, accounting for only around 14 per cent of its total vote in the 2012 election and 15 per cent in the 2007 election (Table 1 ). The party's share of the vote in these districts has been consistently very low since it first contested the 2007 election, despite the fact that its leader, then prime minister Gusmão, is considered to be a political leader capable of uniting all Timorese. While CNRT has made gains in expanding its support in the central and western districts, it has not made any gains in the eastern districts. A regional analysis of CNRT's national vote does not support the argument that regional political affiliations have reached their peak and are easing.

FRETILIN's share of the vote in the eastern districts remains disproportionately high, accounting for around 43 per cent of its total vote in the 2012 election and 52 per cent in the 2007 election (Table 2). The party's share of the vote in these districts has been consistently high since the 2001 Constituent Assembly election. While the eastern districts remain a stronghold, its share of the vote in these districts further declined by 9 per cent in the 2012 election, which does support the argument that the peak of regional political alliances is easing. If a regional analysis of its national vote includes the 2001 Constituent Assembly election, however, the trajectory of decline has eased to an extent. In the 2007 election, its share of the vote in Baucau steeply decreased from 82 per cent in 2001 to 51.38 per cent. Its share of the vote in Lautém, where it has lost the support of a majority of voters, decreased from 62.8 per cent in 2001 to 43.86 per cent. Its share of the vote in Viqueque decreased from 75 per cent in 2001 to 59.52 per cent. During the 2012 election, FRETILIN did not experience as steep a decline. The party's share of the vote in the central and western districts also tell part of this story and while its gains in these districts remain moderate or slight, significant easing of regional political affiliations is unlikely.

55 SEARCH, 'Timor-Leste 2012 Parliamentary Election outcomes'.

56 Michael Leach, 'Post-election Timor-Leste: The parties enter negotiations', Inside Story, 10 July 2012; http://insidestory.org.au/post-election-timor-leste-the-parties-enter-negotiations (last accessed 16 Sept. 2016). 
During both the presidential and parliamentary election campaigns, political leaders often reflected on the legacy of the 2006 crisis. The crisis was predominantly remembered as being caused by historical grievances and disputes between leaders. Political leaders employed rhetoric about reconciliation between 'east' and 'west' and national unity - this contributed to a relatively peaceful election, but did not normalise regional polarisation. Despite such political rhetoric, the events of the crisis were sometimes lobbed like political grenades throughout the campaigns.

In short, the political significance of the east-west divide has endured since the 2006 crisis. Political rhetoric about reconciliation between east and west and national unity contributed to a relatively peaceful election in 2012, but it did not normalise regional polarisation. The divide appears to have entrenched a negative form of political competition which pits east against west. The parliamentary and presidential elections in 2017 will be a further litmus test of identity-building in Timor-Leste.

\section{The implications of regionalism for identity-building}

As in other post-conflict societies, national history in Timor-Leste is heavily contested. In the post-independence period, nationalist narratives are grounded in the resistance and, as a result, grounded in the many social divisions inherent during that period. Nationalism is often described as 'unity through struggle'. Babo-Soares argues that many Timorese proudly refer to the resistance as the 'culmination of previous wars against colonialism' and the 'last stage of their nationalist struggle' ${ }^{57}$ These nationalist narratives have demarcated seemingly incontestable and non-negotiable boundaries between east and west. The boundaries locate lorosa'e at the centre of Timorese history and loromonu on the periphery.

The resistance and its heroes have been memorialised in the national flag, coat-of-arms, Constitution and nationalist heritage sites. ${ }^{58}$ One of the most significant sites of nationalist heritage is Comarca Balide in Dili, the former Portuguese jail built in 1963 and used as an interrogation centre during the Indonesian occupation. ${ }^{59} \mathrm{In}$ the post-independence period, Comarca Balide became a memorial to victims of human rights abuse, the Commission for Reception, Truth and Reconciliation (CAVR) technical secretariat and now holds the CAVR archives, which includes thousands of testimonials collected from victims during the CAVR process between 2001 and 2005. Other significant sites include the 'heroes monument' in Metinaro, east of Dili, a memorial to fallen FALINTIL members, several memorials to the victims of the massacres during the 1999 referendum, and the National Museum of Resistance housed in a former Portuguese court house in Dili.60

The re-emergence of the east-west divide during the 2006 crisis in Timor-Leste and the significant role played by regionalism in successive elections in 2007 and 2012 indicate that identity-building in the new nation-state is fragile. Timorese voted overwhelmingly in favour of independence and, as a result, were assumed to have a strong

57 Babo-Soares, 'Branching from the trunk', p. 81.

58 Michael Leach, 'Difficult memories: The independence struggle as cultural heritage in East Timor', in Places of pain and shame: Dealing with 'difficult heritage', ed. William Logan and Keir Reeves (London: Routledge, 2008), pp. 144-61.

59 Ibid., pp. 148-9.

60 Ibid., pp. 148-56. 
sense of national unity based on the resistance. Timorese had resisted and won, but what had they won in terms of national unity? The emergence of the divide brought this assumption into question. The removal of the external threat of Indonesian colonial power, which was central to the concept of 'us' and 'them', revealed a power struggle between competing groups along with their narratives of the new nationstate. National identity was in fact weak and unable to contain these strong regional identities. A Timorese peacebuilding officer emphasised that 'we have resisted, now we must build'. ${ }^{61}$

During the 2006 crisis Timor-Leste was described as a state in search of a nation. Dennis Shoesmith argues that 'the communal conflict that became so violent in 2006 suggests, however, that the project of building an inclusive national community has not succeeded'. ${ }^{62}$ In an interview in 2009 , a member of parliament stated that 'in the crisis everything that was built was destroyed. We need to start everything again'. 63

In the post-independence period, divisive narratives have re-emerged about relative sacrifice and suffering during the resistance and consequently, which groups are most entitled to the benefits of independence. The narrative about the role played by lorosa'e and loromonu is part of a broader narrative which has emerged in Timor-Leste relating to economic, social and political competition over the relative entitlement of particular individuals and groups to the benefits of independence.

The east-west divide also reflects frustration over slow and uneven socioeconomic development and discontent and disenchantment with the state. The rural-urban divide represents a deep socioeconomic fault line. Wealth distribution is uneven, in particular between rural and urban areas, and it has been exacerbated by the cash payment scheme. Children in urban areas are four times more likely than children in rural areas to be enrolled in secondary education. ${ }^{64}$ Slightly more than half, 57 per cent, of rural households had access to safe drinking water compared to 91 per cent of urban households. ${ }^{65}$ Only 24 per cent of rural households had improved sanitation compared with 80 per cent of urban households. In addition, only 18 per cent of rural households had electricity compared with 87 per cent of urban households. ${ }^{66}$

In this context, narratives of sacrifice and suffering have become a political commodity used to articulate demands for access to scarce state resources and power. Political parties and leaders have used their own roles in the resistance to bolster their legitimacy and moral and political authority, with some claiming that lorosa'e should receive more benefits in the new nation-state. Selver Sahin argues that the emergence of the east-west divide during the 2006 crisis 'exemplifies the intrinsically

61 Personal communication, 6 Dec. 2008 and 19 Aug. 2009.

62 Dennis Shoesmith, 'Timor-Leste: Interpreting violence in a post-conflict state', in The crisis in Timor-Leste, p. 27.

63 Personal communication, 3 Nov. 2009.

64 National Statistics Directorate (NSD) and United Nations Population Fund (UNFPA), Population and Housing Census of Timor-Leste, 2010. Vol. 3: Social and Economic Characteristics (Dili: NSD and UNFPA, 2007), p. xvi.

65 Ibid., p. xx.

66 Ibid., p. xix. 
power-ridden nature of democratic nation-state-building as a sociopolitical process of transformation'. ${ }^{67}$

The current construction of nationalism in Timor-Leste, which is based on the resistance and layered with the divisions of the resistance, is exclusive. It does not support the emergence of an inclusive, unifying national political community in Timor-Leste. Such a construction of nationalism denies the equality of citizens, who should have equal representation and participation in the state. Most significantly, it denies that all citizens are entitled to the benefits of independence, regardless of competing social divisions.

This narrative about the role played by lorosa'e and loromonu during the resistance is one thread woven into a broader narrative of entitlement. The narratives have been informed by social divisions between pro-autonomy and pro-integration groups, lorosa'e and loromonu, diaspora and home-stayers and mestiço, Timorese of mixed decent, and rai nain, 'Indigenous' Timorese, all of which relate to constructions of nationalism which establish varying degrees of authenticity and, as a result, are exclusive. Leach describes these competing claims as "wider "history wars" within the former independence movement over the symbolic "ownership" of the independence struggle, and its core historical narratives'. ${ }^{68}$

These varying degrees of authenticity inform competing claims to access to state power and resources as well as social status. Those who are portrayed as truly Timorese are also portrayed as being most entitled to state power and resources. Those who are portrayed as having made the greatest sacrifice during the resistance are also portrayed as being most entitled to the benefits of independence. These two concepts are interrelated because those who are portrayed as 'heroes' are also portrayed as truly Timorese. These competing narratives diminished the contribution of opposing groups and the rights of these groups 'to be full participants in building the new nation'. ${ }^{69}$ As long as these divisive national discourses remain salient, Timor-Leste will remain vulnerable to identity-based conflict.

Following the 2012 elections, then prime minister Gusmão announced his decision to stand down as prime minister. In February 2015 Gusmão appointed as his successor Rui de Araújo - a member of the clandestine youth movement as a student in Indonesia, and later a FRETILIN party official and former minister for health under the FRETILIN government (2002-2007). Gusmão retained a position in government as head of a super-ministry responsible for strategic planning.

The leadership transition represents a changing of the guard. Damien Kingsbury argues that 'there have been calls in Timor-Leste for the "Generation of ' 75 " leaders to step aside to make way for a younger generation of leaders' ${ }^{70}$ The 'Generation of ' 75 ' refers to an older generation of leaders from the resistance who have retained their

67 Selver B. Sahin, 'Building the nation in Timor-Leste and its implications for the country's democratic development', Australian Journal of International Affairs 65, 2 (2011): 237.

68 Leach, 'Difficult memories', p. 145.

69 Susan Soux, David Gairdner, Sigurd Marstein and Rebecca Engels, 'Review of development cooperation in Timor-Leste: Final report', Norad Report 7 (2007), p. 50.

70 Damien Kingsbury, 'No good time for Xanana Gusmão to let go', East Asia Forum, 25 Oct. 2014; http://www.eastasiaforum.org/2014/10/25/no-good-time-for-xanana-gusmao-to-let-go (last accessed 24 Oct. 2016). 
power in the post-independence period, dominated by former FRETILIN leaders. These leaders are considered to be the heroes of the resistance and, as a result, have widespread moral and political authority in the post-independence period. Nationalist narratives which are grounded in the resistance reinforce their authority.

Prime Minister de Araújo has inherited significant challenges to nation-building, in particular relating to the development of sustainable economic and fiscal policy. Widespread poverty and high unemployment may be exacerbated by a sharp decline in natural resource revenues in the mid-term. Oil and gas provide 90 per cent of Timor-Leste's revenue. ${ }^{71}$ Lao Hamutuk estimates that the Petroleum Fund could be depleted in seven years by 2021 and the fund depleted by 2025. The cash payment scheme has exacerbated uneven wealth distribution in Timor-Leste. Buying off peace is not sustainable.

However, de Araújo's appointment has transformed the political landscape in Timor-Leste to an extent. Emerging leaders, who do not rely on the valorisation of the resistance for their legitimacy and moral and political authority, could re-conceptualise the political landscape and construct new nationalist narratives which are potentially more inclusive because they are not fractured by social fault lines dating to the resistance. As a technocrat de Araújo has formed a cross-party government which may be capable of building national consensus and transcending the social divisions inherited from the resistance era.

\section{Conclusion}

Nation-building is shaped by both material and immaterial structures. Immaterial structures, including the connection between citizens and the state, the transfer of citizens' allegiance from local to central authority, a common sense of purpose and the erosion of social divisions, contribute to building sustainable peace by overcoming the legacy of conflict. Nation-building is not a technical exercise in which nation-building is reduced to the transfer of a liberal democratic state and the nation-state is reduced to its institutions. Identity-building engages with a community's sense of identity, belonging and history and, most significantly, supports the formation of an inclusive national political community.

The re-emergence of the east-west divide during the 2006 crisis in Timor-Leste and the significant role played by regionalism in successive elections in 2007 and 2012 indicates that the divisive national discourse about the competing roles of lorosa'e and loromonu during the resistance has an enduring legacy in the new nation-state. The deep roots of the divide have not yet been dug out. Nation-building in the postindependence period has woven the divide into the fabric of the nation. This divisive discourse undermines the emergence of new narratives of nationalism which support reconciliation between east and west and national unity.

As Myrttinen argues, in the post-independence period, the east-west divide has manifested itself like the pieces of a kaleidoscope, sometimes visible, sometimes barely visible and sometimes seemingly invisible as every turn of the kaleidoscope produces a

71 Integrated Regional Information Networks (IRIN), 'Why Timor-Leste's stability could be deceptive', IRIN News, 18 July 2014; http://www.irinnews.org/report/100363/analysis-why-timor-leste\%E2\%80\% 99s-stability-could-be-deceptive (last accessed 24 Oct. 2016). 
new pattern. ${ }^{72}$ Whether it is visible or not, the divide lingers as shadowy lines intersecting the political landscape in Timor-Leste. These shadowy lines demarcate boundaries of identity and belonging. Re-negotiating these boundaries to include all Timorese would contribute to reconciliation between east and west and overcoming the legacy of conflict in the new nation-state.

72 Myrttinen, 'Timor Leste - A kaleidoscope of conflicts', p. 1. 